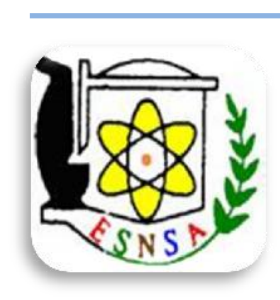

Arab Journal of Nuclear Sciences and Applications

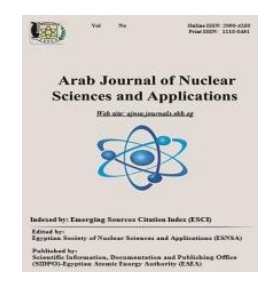

(ESNSA)

\title{
Antiproliferative Effect of Green Tea and Grape Seed Mixture Extracts Combined with $\gamma$-Irradiation on the Growth of Myeloma Cells
}

\author{
H.M. El-Shershaby ${ }^{a}$, W. El-Desouky ${ }^{b}$ and N.H. Ebeid ${ }^{a}$ \\ (a) Labeled Compounds Department, Hot Laboratories Center, Atomic Energy Authority, Egypt \\ ${ }^{(b)}$ Radiation protection Department, Hot Laboratories Center, Atomic Energy Authority, Egypt
}

Received $17^{\text {th }}$ Dec. 2017 The purpose of the present work is to study the effect of green tea and grape seed extracts mixture Accepted $14^{\text {th }}$ Jan. 2018 (GTE-GSE mix) and $\gamma$-irradiation or their combination to enhance the antiproliferative effect on the growth of myeloma cells. To investigate this effect, a myeloma cell line SP2/OR was cultured in RPMI1640 medium; total count and viability $\%$ were daily calculated. Myeloma cells $(1 \mathrm{X} \mathrm{10} / \mathrm{ml})$ were treated with GTE-GSE mix concentrations $(100-1000 \mathrm{ng} / \mathrm{ml}), \gamma$-irradiation doses $(0.5-10 \mathrm{~Gy})$ and their combination for 6 days. Evaluation of Caspase 8 and 9 activities were measured. Cell culture media and GTE-GSE mix activity were determined using DPPH method.The results of this study indicate that the most effective dose of GTE-GSE mix on myeloma cells growth inhibition and viability \% was $1000 \mathrm{ng} / \mathrm{ml}$, while the effective dose of $\gamma$-irradiation was $8 \mathrm{~Gy}$ where viability percentage was zero. The obtained results indicate that treatment with GTE-GSE mix plus $\gamma$-irradiation combination $(700 \mathrm{ng} / \mathrm{ml}+6 \mathrm{~Gy})$ resulted in zero\% growth inhibition at $4^{\text {th }}$ day. Treatment with combination dose induced activation of caspase 8 and caspase 9 levels more than GTE-GSE mix and $\gamma$-irradiation alone. Treatment with GTEGSE mix and $\gamma$-irradiation individually resulted in a significant reduction in DPPH activity to $62 \%$ while in combination treatment was $\mathbf{7 3 . 5 \%}$. It could be concluded that the treatment with GTE-GSE mix plus $\gamma$-irradiation $(700 \mathrm{ng} / \mathrm{ml}+6 \mathrm{~Gy})$ combination resulted in a marked increase of growth inhibition levels, apoptosis and cancer cells regression when compared with each agent alone. GTE-GSE mix plus $\gamma$ irradiation combination had an antiproliferative effect on the growth of myeloma cells.

Keywords: Antiproliferative/ Myeloma cells/ Green tea extract/ Grape seed extract/ $\gamma$-Irradiation

\section{Introduction}

Multiple myeloma (MM) is a mature B-cell malignancy characterized by monoclonal expansion of plasma cells in the bone marrow. This leads to bone destruction, marrow failure and accompanied by excessive production of monoclonal immunoglobulins Myeloma develops when plasma cells undergo malignant change and become myeloma cells. These myeloma cells multiply without any proper order, forming collections known as tumors that accumulate in different parts of the body, especially in the bone marrow and on the surfaces of different bones in the body. Osteolytic lesions result from increased bone resorption due to stimulation of osteoclast formation and activity that occurs in close proximity to myeloma cells[1].

$\mathrm{MM}$ is the second most common hematologic malignancy and accounts for as many as $20 \%$ of deaths from hematological malignancies and $2 \%$ of deaths from all cancers [2]. The average patient age at diagnosis of multiple myeloma is about 68 years, and $99 \%$ of patients diagnosed are older than 40 years [3].

Green tea (Camellia sinensis, family Theaceae) is still one of the most commonly consumed beverages worldwide. Green tea is made from

Corresponding author:waeld5@hotmail.com

DOI: 10.21608/ajnsa.2018.2329.1023

(C) Scientific Information, Documentation and Publishing Office (SIDPO)-EAEA 
leaves of camellia sinensis that have undergone minimal oxidation during processing.

The chemical composition of green tea extract (GTE) is complex, consisting of polyphenols (catechins and flavanoids), alkaloids (caffeine, threobromine, the ophylline, etc.), volatile oils, polysaccharides, amino acids, lipids, vitamin $\mathrm{C}$, minerals and other uncharacterized compounds [4]. Among these, the largest component present in green tea leaves is carbohydrates (including cellulosic fiber) and the simplest compounds are catechins, a group of flavanoids called flavan-3-ols [5]. These catechins are synthesized in tea leaves through malonic acid and shikimic acid metabolic pathways with gallic acid as an intermediate derivative [6]. Catechins and other polyphenols have antioxidant activities [7]. They act as antioxidants in Vitro by sequestering metal ions and by scavenging reactive oxygen and nitrogen species[8,9].

The antioxidant capacity of polyphenols present in green tea has been reported to be both chemoprotective and therapeutic[10]. The ability to inhibit the effects of various mutagens in cultured cell lines has also been observed[11]. They may also work indirectly as antioxidants through their effects on the activity of transcription factors and enzymes[8].The antioxidant properties of green tea and its constituent catechins were evaluated in a number of diseases associated with Reactive Oxygen Species (ROS), such as cancer and cardiovascular and neurodegenerative diseases. Several epidemiological studies as well as studies in animal models have shown that green tea can confer protection against various cancers such as those of the skin, breast, prostate, and lung [12].

Grape seed extract (GSE) is a by-product derived from the grape seeds (Vitis vinifera) (from grape juice and wine processing) that is extracted, dried and purified to produce a polyphenolic compound rich extract [13]. Grape seed extract sold commercially as dietary supplement listed on the "Everything Added to Food in the United States (EAFUS)" and has Generally Recognized As Safe (GRAS) status approved by the Food and Drug Administration (FDA). The composition and properties of grape seeds have been investigated, and reported to have many favorable effects on human health such as the lowering of low-density lipoprotein [14-16], reduction of cardiovascular diseases and cancer [17].

The GSE of Vitis vinifera proved to have free radical scavenging properties [18], reduce the risk of chronic disease by protecting against free radical mediated damage $[19,20]$ and prevent the incidence of stroke due to its radical scavenging action and inhibition of lipid peroxidation [21].

Grape seed extract exhibits cytotoxicity toward some cancer cells such as skin [22], breast[23], colon[24], lung and gastric [25], Multiple myeloma[26] and prostate cancers [27] while enhancing the growth and viability of normal cells[28]. Grape seed extract lethality is regulated by multiple mechanisms including inactivation of cytoprotective pathways such as phosphatidylinositol 3-kinase/protein kinase B[24], activation of stress related pathway [29], activation of Chk2 and p53 [30], mitochondrial damage leading to cytochrome $\mathrm{c}$ and apoptosis-inducing factor release [27].

The phenolic compounds in grapes and grape seed extracts can be divided into two groups: (a) phenolic acids and related compounds and (b) flavonoids. The most common phenolic acids in grape include cinnamic acids (coumaric acid, caffeic acid, ferulic acid, chlorogenic acid, and neochlorogenic acid) and benzoic acids (phydroxybenzoic acid, protocatechuic acid, vanillic acid, and gallic acid). Flavonoids include colorless flavan-3-ols (such as (+)-catechin, (-)-epicatechin, and their polymers and their ester forms with galactic acid or glucose), colored flavanones (the most common flavanone in food is quercetin), and red and blue anthocyanins [31].

Phenolic compounds possess a structure that confers on them an antioxidant property, which has been demonstrated to exert a novel spectrum of biological, pharmacological, therapeutic, and chemoprotective effects against oxygen free radicals and oxidative stress [32]. All these constituents have been reported to exhibit antioxidant activity in vivo and in vitro as they can scavenge many superoxide radicals and thereby play an important role in the inhibition of carcinogenesis [18]. 
Also, these constituents can protect against DNA damage caused by free radicals [33,34]. Several studies have indicated that extracts obtained from grape seed inhibit enzyme systems that are responsible for the production of free radicals, and that they are anti-mutagenic and anti-carcinogenic $[35,36]$. For this reason, GSE is widely consumed as a dietary supplement and could be useful in synergizing the efficacy of chemotherapeutic agents in cancer treatment.

The programmed cell suicide or apoptosis is a regulatory system for balancing the homeostasis situation during the growth, development and differentiation among multicellular organisms. The appearance of any type of disorders may lead to a wide range of diseases including neurological, immunological, and cancerous problems[37]. The performance of a successful apoptosis process is directly associated with inducers, caspase enzymes, related genes and signaling pathways [38].

Caspases are a family of endoproteases that play essential roles in apoptosis, necrosis, and inflammation. Caspases involved in apoptosis have been sub classified by their mechanism of action and are either initiator caspases (caspase 2, 8 and 9) or executioner caspases (caspase 3,6 and 7)[39]. Initiator caspases activate executioner caspases that subsequently coordinate their activities to demolish key structural proteins and activate other enzymes[40].

Radiation therapy ( $\gamma$-radiation) is to deliver radiation doses and schedules that kill cancer cells while preserving normal tissue function. The biological effects of ionizing radiation vary with the dose, the dose rate, physical nature of radiation and the type of cell or tissue irradiated. $\gamma$-radiation is used in the treatment of cancer leading to apoptosis in tumor cells[41].

This study aims to evaluate the antiproliferative effect of GTE-GSE mixture, $\gamma$-irradiation and their combination on the growth of myeloma cells in vitro.

\section{Materials and Methods}

Myeloma cell line

SP2/OR myeloma cell line was supplied through the EGY/2/007, 1998, IAEA project.
Chemicals

RPMI-1640, Foetal bovine serum, Antibiotic antimycotic mixture $(10,000$ Unit penicillin, $10 \mathrm{mg}$ streptomycin and $25 \mu \mathrm{g}$ amphotericin $\mathrm{B} / 1 \mathrm{ml} 0.9 \% \mathrm{Na}$ $\mathrm{Cl})$, L-glutamine (200 $\mathrm{mM}$ solution), were obtained from Sigma-Aldrich Co. USA. Green tea leaves and grape seeds were bought from the local market.

\section{Irradiation source and technique}

The source of irradiation was ${ }^{137} \mathrm{Cs}$ gamma cell 40 , installed in the National Center for Research and Radiation Technology (NCRRT), Atomic Energy Authority, Cairo, Egypt. Cell culture flasks were placed into boxes and were placed in the irradiation chamber of the gamma cell. The doses used for cell cultures were $0.5,1.5,3,6,8$ and 10 Gy at a dose rate $=0.175 \mathrm{~Gy} / \mathrm{min}$ throughout the period of irradiation.

\section{Green tea and grape seed extracts preparation}

Green tea extract (GTE) was separated by maceration of $100 \mathrm{~g}$ grinded tea leaves for 24 hours three times in $250 \mathrm{ml}$ of $95 \%$ ethanol at ambient conditions[42,43]. Collected extracts were filtered and centrifuged (7000 rpm, $15 \mathrm{~min})$, ethanol was evaporated on a rotary evaporator (RVO 200 A, INGOS). The powdered GTE was kept frozen at $-18^{\circ} \mathrm{C}$ until further use.

Grape seed extract (GSE) was prepared according to Ahn et al and El-Desouky et al $[44,45]$. Grape seeds (GS) were dried at $50^{\circ} \mathrm{C}$ for 3 days in drying oven. GS grinded to fine powder by grinder (Moulinex, model 721, France). About $100 \mathrm{~g}$ of GS powder was extracted in $500 \mathrm{ml}$ of $50 \%$ ethanol and left for one day at room temperature. The extract was filtered through Büchner funnel followed by removal of ethanol using vacuum rotary evaporator at $40^{\circ} \mathrm{C}$. The residue obtained was dissolved in water and kept at $4{ }^{\circ} \mathrm{C}$ until further use.

The obtained extracts were mixed to prepare GTEGSE mixture with a ratio of 1:2 (100 mg GTE: 200 $\mathrm{mg}$ GSE). The mixture was determined previously by LC/DAD/MS HPLC and kept frozen at $-20^{\circ} \mathrm{C}$ until further use $[43,45]$.

\section{Growth of myeloma cells}

The myeloma cells SP2/OR were maintained in RPMI-1640 medium. The RPMI- 1640 media supplemented with $10 \%$ foetal bovine serum, $1 \%$ antibiotic antimycotic and $1 \%$ L-glutamine. The 
cells were plated in $25 \mathrm{~cm}^{2}$ culture flasks and incubated at $37^{\circ} \mathrm{C}$ in a humidified air with $5 \% \mathrm{CO}_{2}$ until cells growth enter log-phase with viability > $95 \%$. The cells were recounted with a viability check daily prior to adjustment of the cell count to $2.5-5 \times 10^{5}$ cells. This process continued until cells doubling time of 18-24 hrs was achieved with a viability $>95 \%$ and the final cell density was 1 $1.5 \times 10^{6} / \mathrm{ml}[46,47]$. To determine total number of cell and viability $\%, 100 \mu \mathrm{l}$ of cells suspension was mixed with $100 \mu 1$ of trypan blue dye and counted on hemocytometer[48].

The total count and viability $\%$ of myeloma cells were calculated according to the following equations:

Total counts of myeloma cells $/ \mathrm{ml}=$ Total number of cells /Number of square counted $\times 2 \times 10^{4}$

$$
\text { Viability }(\%)=\frac{\text { Number of viable cells } / \mathrm{ml}}{\text { Total Number of cells } / \mathrm{ml}} \times 100
$$

Treatment of myeloma cells SP2/OR

Effect of GTE-GSE mixture on myeloma cells

GTE-GSE mixture was added at variable concentrations of $(100,300,400,500,700,1000$ $\mathrm{ng} / \mathrm{ml})$ into myeloma cells $\left(1 \times 10^{6} / \mathrm{ml}\right)$ and incubated at $37^{\circ} \mathrm{C}$ with $5 \% \mathrm{CO}_{2}$ for 6 days. The total count and viability of myeloma cells were calculated daily.

\section{Effect of $\gamma$-Irradiation on Myeloma Cells}

Myeloma cells $\left(1 \times 10^{6} / \mathrm{ml}\right)$ were treated with $\gamma$ irradiation at variable doses $(0.5,1.5,3,6,8$ and $10 \mathrm{~Gy})$. The myeloma cells after exposure to $\gamma$ irradiation were incubated for 6 days at $37^{\circ} \mathrm{C}$ with $5 \% \mathrm{CO}_{2}$. Total count and viability of myeloma cells were calculated daily for each dose.

Effects of GTE-GSE mixture and $\gamma$-irradiation combination on myeloma cells

Myeloma cells $\left(1 \times 10^{6} / \mathrm{ml}\right)$ were treated with the most effective doses of GTE-GSE mix (500, 700 and $1000 \mathrm{ng} / \mathrm{ml}$ ), then exposed to different doses of $\gamma$-irradiation $(0.5,1.5,3,6,8$ and $10 \mathrm{~Gy})$. Treated myeloma cells were incubated at $37^{\circ} \mathrm{C}$ with $5 \% \quad \mathrm{CO}_{2}$ for 6 days. The total count and viability were calculated daily.

\section{Caspase activity assays}

Myeloma cells $\left(1 \times 10^{6} / \mathrm{ml}\right)$ were treated with GTE-GSE mix, $\gamma$-irradiation and GTE-GSE mix + $\gamma$-irradiation combination of 48 hours .The cells were washed two times with $2 \mathrm{ml}$ phosphate buffer saline $(0.05 \mathrm{M} \mathrm{pH} 7.4)$ and subsequently treated with lysis buffer (50 mM Tris-HCl, $\mathrm{pH} 7.4,150$ $\mathrm{mM} \mathrm{NaCl}, 1 \%$ Nonidet P-40 and 1\% SDS) for 10 min on ice bath to lyse cells ( $25 \mu 1$ of lysis buffer / $1 \times 10^{6}$ cells). The cell lysate was centrifuged at $10.000 \mathrm{xg}$ for $1 \mathrm{~min}$. The supernatant was transferred to a new tube and was kept in ice bath. Each reaction requires $50 \mu 1$ of cell lysate, $50 \mu 1$ of reaction buffer (saline, glycerol and detergent) was added to each reaction (before using reaction buffer $10 \mu \mathrm{l}$ of fresh DTT stock (dithiothreitol) was added to $1 \mathrm{ml}$ of reaction buffer). $5 \mu \mathrm{l}$ of caspase colorimetric substrate (LEHD-PNA) was added to each reaction, and then the plate was incubated at $37^{\circ} \mathrm{C}$ for $1-2$ hours. The absorbance of each well was detected using spectrophotometer at a wave length of $405 \mathrm{~nm}$ [49].

\section{DPPH scavenging assay}

The activity of cell culture media and GTE-GSE mix was measured based on the radical scavenging ability in reaction with a stable DPPH free radical according to Blois ${ }^{[50]}$. Diphenylpicrylhydrazine (DPPH) is usually used as a reagent to evaluate free radical and accepts an electron or hydrogen radical to become a stable molecule.

Briefly, $0.1 \mathrm{mM}$ of DPPH in ethanol was prepared and $1 \mathrm{ml}$ of this solution was added to $1 \mathrm{ml}$ from the supernatant of cell culture media treated with GTE-GSE mix $(100,300,400,500,700$ and 1000 $\mathrm{ng} / \mathrm{ml})$. The mixture was shaken and allowed to stand at room temperature for $30 \mathrm{~min}$ in the dark. Then the absorbance was measured at $517 \mathrm{~nm}$. The radical scavenging activities Butylated hydroxytoluene (BHT) and Butylated hydroxyanisole (BHA) were determined also as positive controls. Minimum absorbance of the reaction mixture indicated maximum free radical scavenging activity. The blank readings were taken and the capability to scavenge DPPH radical was calculated using the following equation:

DPPH ${ }^{*}$ scavenging activity $(\%)=\left[\left(\mathrm{A}_{0}-\mathrm{A}_{1} / \mathrm{A}_{0}\right)\right] \times 100$

Where,

$\mathrm{A}_{0}=$ Absorbance of control reaction (containing reagents except the test compounds).

$\mathrm{A}_{1}=$ Absorbance in presence of the tested cell culture media. 


\section{Results}

GTE-GSE mixture induces inhibition of myeloma cell growth

Myeloma cells SP2/OR $\left(1 \times 10^{6} / \mathrm{ml}\right)$ were cultured in the presence or absence of GTE-GSE mix at various concentrations $(100-1000 \mathrm{ng} / \mathrm{ml})$ for 6 days and total count and viability were calculated daily. GTE-GSE mix induced both time and dosedependent decrease in survival of myeloma cells, as shown in Fig. (1). The viability $\%$ decreased from 91 to $79 \%$ at dose $100 \mathrm{ng}$, from 81 to $48 \%$ at dose $300 \mathrm{ng}$, from 70 to $39 \%$ at dose $400 \mathrm{ng}$, from 65 to $32 \%$ at dose $500 \mathrm{ng}$, from 53 to $11 \%$ at dose $700 \mathrm{ng}$ and from 44 to $7 \%$ at dose $1000 \mathrm{ng}$ at the $6^{\text {th }}$ day.
These results indicated that low doses of GTEGSE mix had a slight effect on survival of myeloma cells while cell viability $\%$ was significantly inhibited by $1000 \mathrm{ng}$ of GTE-GSE mix treatment in a dose-and time-dependent manner. Also, it was observed that the most effective doses of GTE-GSE mix on myeloma cells viability were 500, 700 and $1000 \mathrm{ng} / \mathrm{ml}$. Therefore, the $1000 \mathrm{ng} / \mathrm{ml}$ as an optimum dose could be selected and used for treatment or inhibition of growth of myeloma cells.

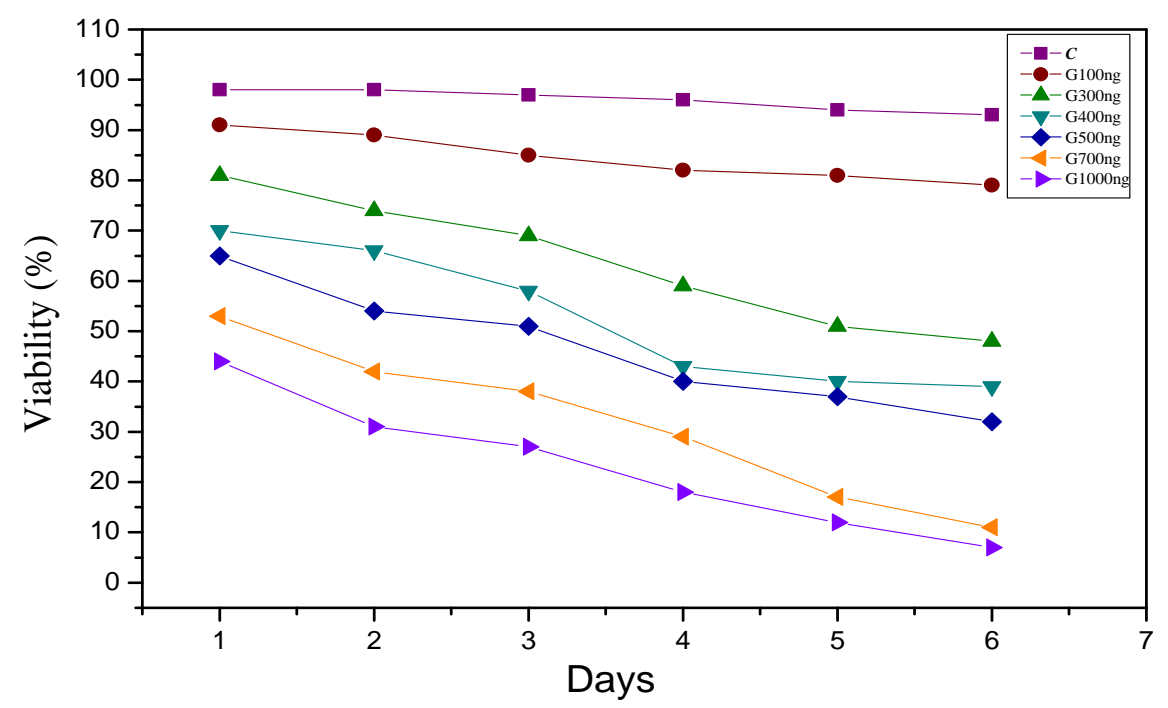

Fig. (1): Effect of variable concentrations of GTE-GSE mixture on viability \% of myeloma cells

Effect of $\gamma$-irradiation on viability \% of myeloma cells

Fig. (2) illustrates the effect of variable doses (D) of $\gamma$-irradiation $(0.5,1.5,3,6,8$ and $10 \mathrm{~Gy})$ on the growth of myeloma cells during lifespan during 6 days period time compared to the control group. The viability \% of myeloma cells for each dose $(0.5,1.5,3$ and $6 \mathrm{~Gy})$ decreased from (84 to $33 \%$, 78 to $29 \%, 68$ to $21 \%$ and 61 to $15 \%$ ), respectively at the $6^{\text {th }}$ day. Also, the viability $\%$ decreased from (44 to $0 \%$ with 8 Gy at the $4^{\text {th }}$ day) and from 26 to $0 \%$ with $10 \mathrm{~Gy}$ at the second day.

From these results, it can be concluded that the effective dose of $\gamma$-irradiation for treatment of myeloma cells was $8 \mathrm{~Gy}$ where at this dose the viability $\%$ of myeloma cells reach $0 \%$ at the $4^{\text {th }}$ day from exposure of $\gamma$-irradiation.
Effect of GTE-GSE mixture plus $\gamma$-irradiation combination on viability \% of myeloma cellsIn order to obtain the optimum dose from GTE-GSE mix that could be used in combination with $\gamma$ irradiation, the most effective three doses of GTEGSE mix at 500, 700 and $1000 \mathrm{ng} / \mathrm{ml}$ were used individually with different doses of $\gamma$-irradiation ranged from (0.5 - $10 \mathrm{~Gy})$.

It was observed from Fig. (3a) that the viability (\%) of myeloma cells decreased from 62 to $17 \%$ at D1 $(500 \mathrm{ng}+0.5 \mathrm{~Gy})$, from 53 to $13 \%$ at D2 (500 ng $+1.5 \mathrm{~Gy})$, from 48 to $11 \%$ at D3 (500 ng $+3 \mathrm{~Gy})$ and from 39 to $6 \%$ at D4 (500 ng + $6 \mathrm{~Gy})$ at the $6^{\text {th }}$ days, where the viability decreased from 26 to $0 \%$ at D5 (500 $\mathrm{ng}+8 \mathrm{~Gy})$ at the $4^{\text {th }}$ days and the growth of cells reached to zero \% with D6 (500 ng + 10 Gy) after the first day. 


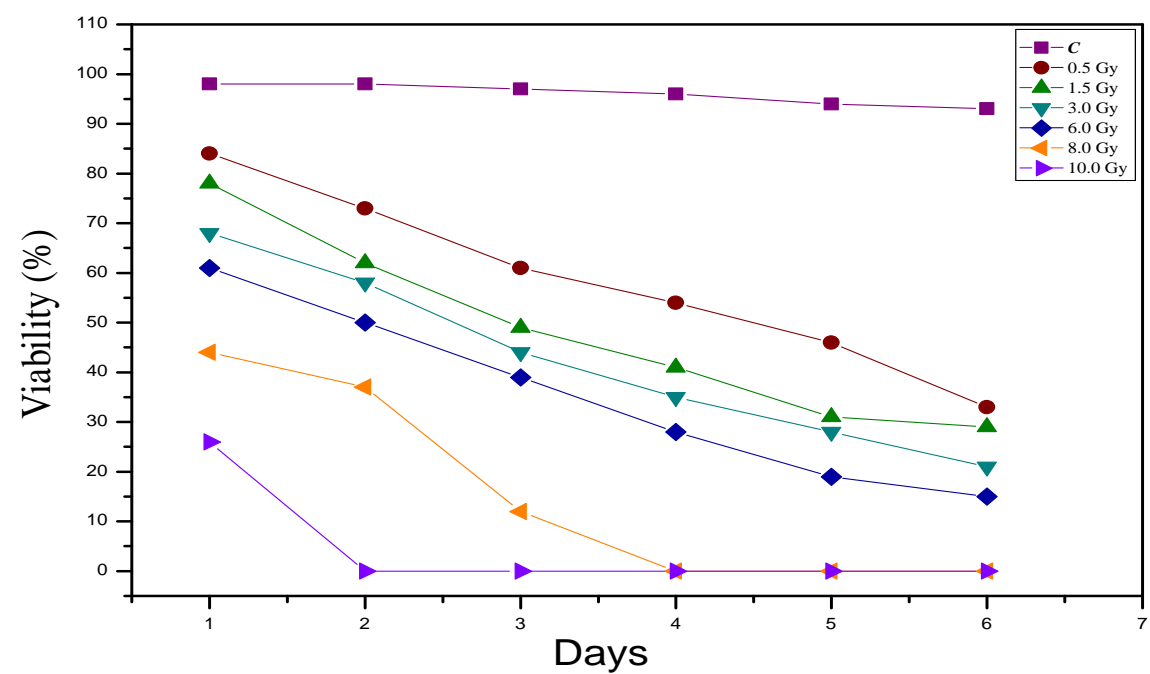

Fig. (2): Effect of variable doses of $\gamma$-irradiation on viability \% of myeloma cells

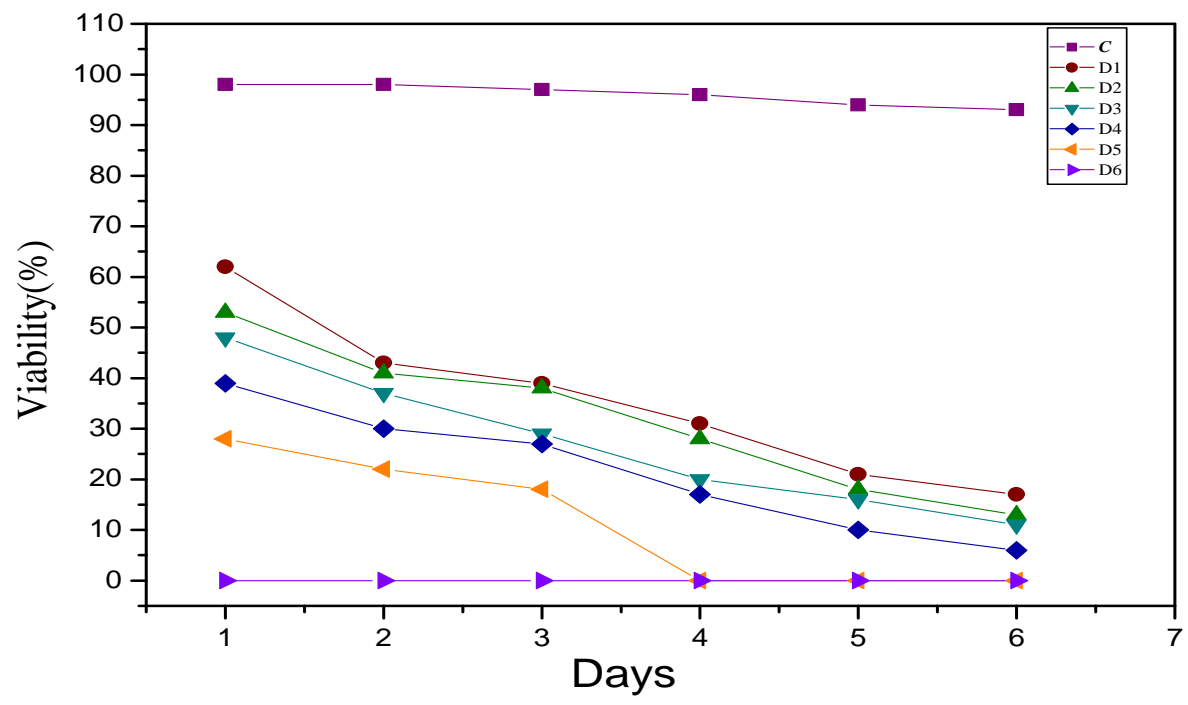

Fig. (3a): Effect of GTE-GSE mixture at concentration $(500 \mathrm{ng} / \mathrm{ml})$ and combined with different doses of $\gamma$ irradiation on viability \% of myeloma cells. $C=$ control, $D 1=500 \mathrm{ng}+0.5 \mathrm{~Gy}, \mathrm{D} 2=500 \mathrm{ng}+1.5 \mathrm{~Gy}$, $\mathrm{D3}=500 \mathrm{ng}+3.0 \mathrm{~Gy}, \mathrm{D} 4=500 \mathrm{ng}+6.0 \mathrm{~Gy}, \mathrm{D5}=500 \mathrm{ng}+8.0 \mathrm{~Gy}$ and D6= 500 $\mathrm{ng}+10.0 \mathrm{~Gy}$

The data in Fig. (3b) show that the viability $\%$ of myeloma cells decreased from 51 to $11 \%$ at D1 (700 ng $+0.5 \mathrm{~Gy})$, from 49 to $10 \%$ at $\mathrm{D} 2(700 \mathrm{ng}$ $+1.5 \mathrm{~Gy})$, from 43 to $9 \%$ at D3 (700 $\mathrm{ng}+3 \mathrm{~Gy})$ and from 35 to zero \% at D4 (700 ng +6 Gy) during 6 days, where the viability \% and growth of myeloma cells with D5 (700 ng +8 Gy) decreased from 22 to zero $\%$ at the $3^{\text {rd }}$ day and with D6 (700 $\mathrm{ng}+10 \mathrm{~Gy})$ the growth of cells reached to zero $\%$ at the first day.

These results indicated that the treatment with GTE-GSE mix in combination with $\gamma$-irradiation at D4 (700 ng + 6 Gy) during 6 days gave more growth inhibition than either GTE-GSE mix or $\gamma$ irradiation individually in myeloma cells.

The effect of combination treatment of GTE-GSE mix $(1000 \mathrm{ng})$ in addition to different doses of $\gamma$ - 
irradiation ranged from $(0.5 \mathrm{~Gy}$ to $10 \mathrm{~Gy})$ on viability $\%$ of myeloma cells were illustrated in Fig. (3c). The viability (\%) of myeloma cells in the present study was decreased from 48 to $8 \%$ at D1 $(1000 \mathrm{ng}+0.5 \mathrm{~Gy})$, from 41 to $6 \%$ at D2 (1000 ng $+1.5 \mathrm{~Gy})$ and from 35 to $4 \%$ at D3 (1000 ng + 3 Gy) during 6 days where the viability $(\%)$ decreased from 27 to zero \% with D4 (1000 ng + 6 Gy) at $5^{\text {th }}$ day, from 22 to zero $\%$ with D5 (1000 ng $+8 \mathrm{~Gy})$ at $3^{\text {rd }}$ day and the viability $\%$ of cells reached to zero \% with D6 $(1000 \mathrm{ng}+10 \mathrm{~Gy})$ at the $1^{\text {st }}$ day.The obtained results from Fig. (3a, 3b, 3c) indicated that the treatment with GTE-GSE mix combined with $\gamma$-irradiation $(700 \mathrm{ng} / \mathrm{ml}+6$ Gy) gave more growth inhibition at the $4^{\text {th }}$ day than either GTE-GSE mix or $\gamma$-irradiation individually in myeloma cells during 6 days. While, the combination treatment of $1000 \mathrm{ng} / \mathrm{ml}+6 \mathrm{~Gy}$ allowed to growth inhibition at the $5^{\text {th }}$ day. Thus, it could be stated that the best combination treatment is $700 \mathrm{ng} / \mathrm{ml}+6 \mathrm{~Gy}$.

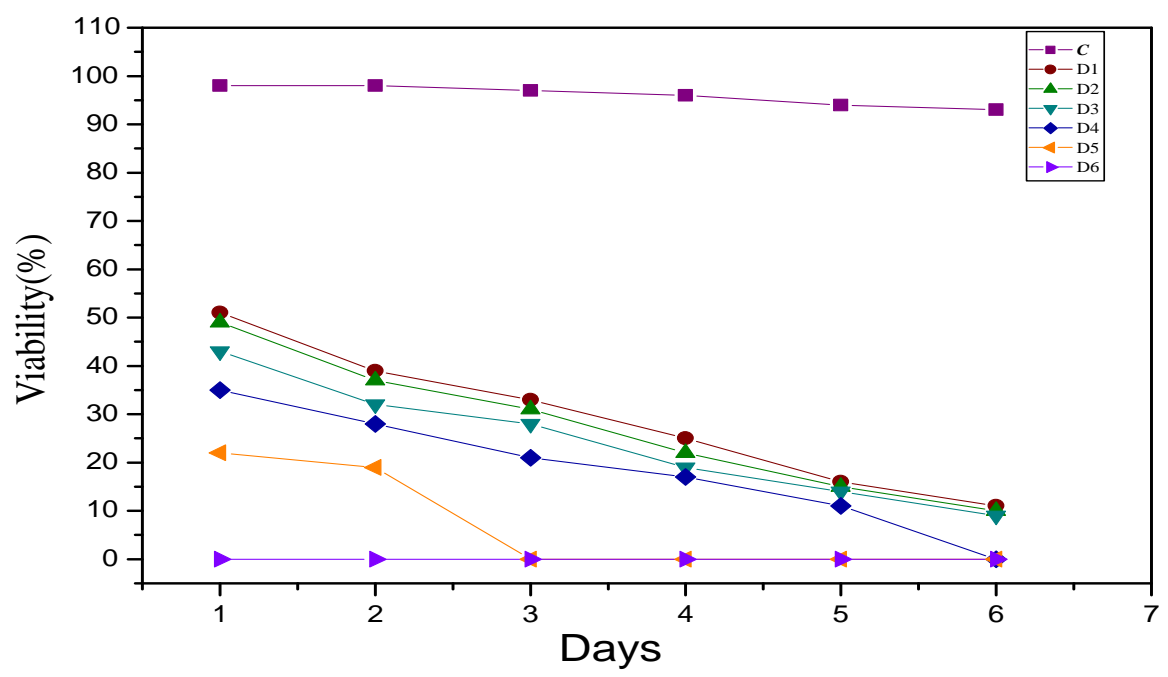

Fig. (3b): Effect of GTE-GSE mixture at concentration $(700 \mathrm{ng} / \mathrm{ml})$ and combined with different doses of $\gamma$ irradiation on viability \% of myeloma cells. $C=$ control, $D 1=700 \mathrm{ng}+0.5 \mathrm{~Gy}, \mathrm{D} 2=700 \mathrm{ng}+1.5 \mathrm{~Gy}, \mathrm{D3}=700 \mathrm{ng}$ $+3.0 \mathrm{~Gy}, \mathrm{D} 4=700 \mathrm{ng}+6.0 \mathrm{~Gy}, \mathrm{D} 5=700 \mathrm{ng}+8.0 \mathrm{~Gy}$ and $\mathrm{Db}=700 \mathrm{ng}+10.0 \mathrm{~Gy}$

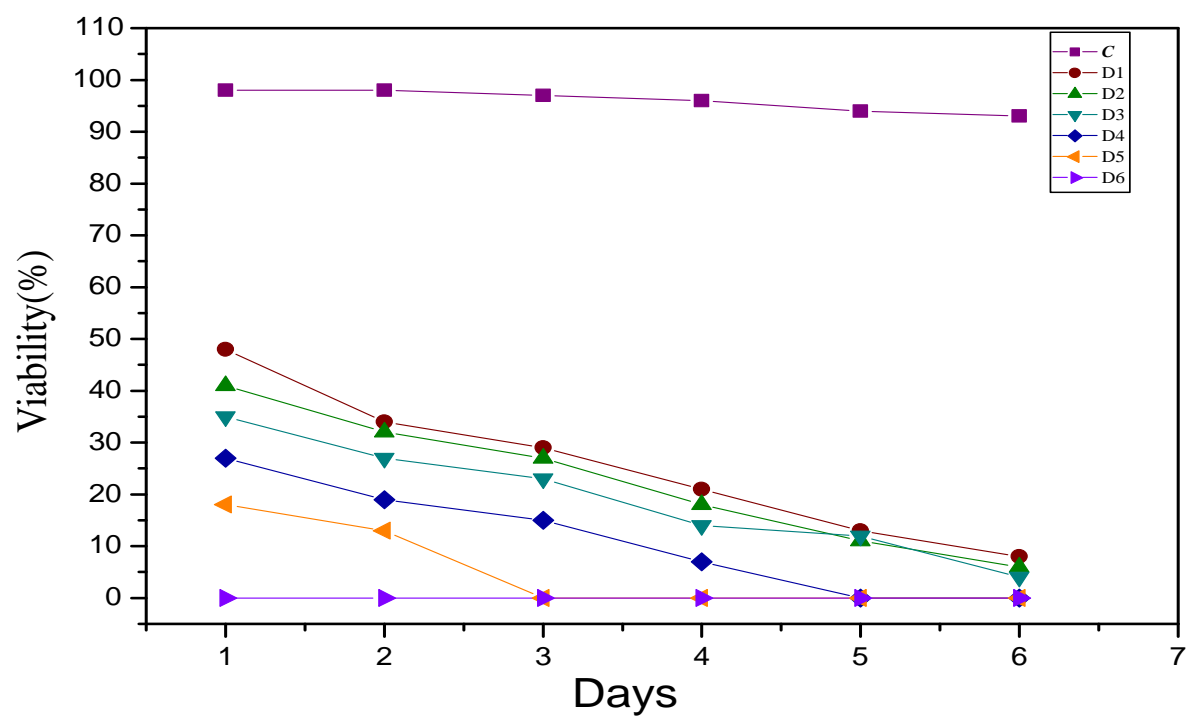

Fig. (3c): Effect of GTE-GSE mixture at concentration $(1000 \mathrm{ng} / \mathrm{ml})$ and combined with different doses of $\gamma$-irradiation on viability \% of myeloma cells. $C=$ control, $D 1=1000 \mathrm{ng}+0.5 \mathrm{~Gy}, \mathrm{D} 2=1000 \mathrm{ng}+1.5 \mathrm{~Gy}$, $\mathrm{D3}=1000 \mathrm{ng}+3.0 \mathrm{~Gy}, \mathrm{D} 4=1000 \mathrm{ng}+6.0 \mathrm{~Gy}, \mathrm{D5}=1000 \mathrm{ng}+8.0 \mathrm{~Gy}$ and D6=1000 ng $+10.0 \mathrm{~Gy}$ 


\section{Evaluation of caspase activity}

In order to gain a better understanding of the apoptotic pathways activated by GTE-GSE mix, $\gamma$ irradiation and combined treatment (GTE-GSE mix $+\gamma$-irradiation) in myeloma cells, and to delineate the mediators responsible for this process, we cultured the cells in the presence or absence of GTE-GSE mixture, $\gamma$-radiation and combined treatment and subsequently investigated the activation of caspases 8 and 9 .

The obtained results in Table (1) demonstrated that the treatment with GTE-GSE mixture with the combination with $\gamma$-irradiation conferred increased the activity of caspases 8 to $0.3 \mathrm{IU} / \mathrm{ml}$ in comparison with the control at $0.15 \mathrm{IU} / \mathrm{ml}$ and caspase 9 to $0.29 \mathrm{IU} / \mathrm{ml}$ compared with the control at $0.08 \mathrm{IU} / \mathrm{ml}$ during $48 \mathrm{~h}$ post-treatment and ultimately causing apoptosis of myeloma cells. The treatment with GTE-GSE mix at $700 \mathrm{ng} / \mathrm{ml}+$ $\gamma$-irradiation 6 Gy combination induced the activation of caspase 8 and caspase 9 more than GTE-GSE mix and $\gamma$-irradiation alone causing more apoptosis.

The obtained results of this study showed that the combined treatment with GTE-GSE mixture (700 $\mathrm{ng} / \mathrm{ml}$ ) plus $\gamma$-irradiation (6 Gy) at the $4^{\text {th }}$ day resulted in a significant increase of growth inhibition levels and apoptosis when compared with each treatment alone. Also, GTE-GSE mixture induced a synergistic apoptosis in myeloma cell lines.

Table (1): The level of caspase activities (IU/ml) in treated myeloma cells compared to control

\begin{tabular}{|c|c|c|}
\hline $\begin{array}{c}\text { Myeloma Treatment } \\
\text { Groups }\end{array}$ & Caspase-8 & Caspase-9 \\
\hline $\begin{array}{c}\text { Control } \\
\text { (Myeloma cell without treatment) }\end{array}$ & $0.15 \pm 0.02$ & $0.08 \pm 0.03$ \\
\hline $\begin{array}{c}\text { GTE -GSE } \mathbf{~ m i x} \\
(\mathbf{5 0 0 ,} \mathbf{7 0 0} \text { and 1000 } \mathbf{~ g / m l )}\end{array}$ & $0.23 \pm 0.04$ & $0.19 \pm 0.02$ \\
\hline $\begin{array}{c}\boldsymbol{\gamma} \text {-irradiation } \\
(\mathbf{6}, \mathbf{8} \text { and 10 Gy) }\end{array}$ & $0.26 \pm 0.03$ & $0.23 \pm 0.04$ \\
\hline $\begin{array}{c}\text { irradiation } \\
(\mathbf{7 0 0} \mathbf{~ n g} / \mathbf{m l}+\mathbf{6 . 0} \text { Gy })\end{array}$ & $0.3 \pm 0.04$ & $0.29 \pm 0.03$ \\
\hline
\end{tabular}

Data are presented as mean $\pm \mathrm{SD}, \mathrm{n}=5$. GTE: green tea extract, GSE: grape seed extract

\section{DPPH radical scavenging activity}

The free radical scavenging activity of different concentrations of GTE-GSE mixture $(100,300$, 400, 500, 700 and $1000 \mathrm{ng} / \mathrm{ml}$ ), different $\gamma$ irradiation doses $(0.5,1.5,3,6,8$ and $10 \mathrm{~Gy})$ and combination treatment (GTE-GSE mix with $\gamma$ irradiation) $500,700,1000 \mathrm{ng} / \mathrm{ml}$ were determined by the DPPH method compared with BHA and BHT as standard and the results are shown in Table (2).

The results showed that myeloma SP2/OR cells $\left(1 \times 10^{6} / \mathrm{ml}\right)$ exposed to $\gamma$-irradiation only with doses 6,8 and 10 Gy gave higher percentages of DPPH 51.8, 62.3 and $77.4 \%$ respectively. While treatment with the GTE-GSE mixture only afforded to increase DPPH activity to $31.2,46.2$, $54.3,59.8$ and $69.3 \%$ when the mixture concentrations increased to $300,400,500,700$ and $1000 \mathrm{ng} / \mathrm{ml}$, respectively in comparison to BHA and BHT (\%) as standard.

Both GTE-GSE mixture and $\gamma$-irradiation treatment individually for myeloma supernatant without treatment resulted in more reduction that is significant in DPPH radical activity percentage to $62.0 \%$ while, for myeloma supernatant with the combination treatment $(700 \mathrm{ng} / \mathrm{ml}$ plus $6 \mathrm{~Gy})$ reached $73.5 \%$. 
Table (2): DPPH Radical Scavenging Activity of different GTE-GSE mixture concentrations $(100,300,400,500,700$ and $1000 \mathrm{ng} / \mathrm{ml})$, different $\gamma$-irradiation doses $(0.5,1.5,3,6,8$ and $10 \mathrm{~Gy})$ and the combination treatment $(500,700$, $1000 \mathrm{ng} / \mathrm{ml}$ ) compared with BHA and BHT as standard

\begin{tabular}{|c|c|c|c|c|}
\hline$\underbrace{\text { Type of Treat }}_{\text {Groups }}$ & Sample & $\begin{array}{c}\text { DPPH } \\
\text { Activity }(\%)\end{array}$ & BHA (\%) & BHT (\%) \\
\hline $\begin{array}{c}\text { Myeloma cells without } \\
\text { treatment }\end{array}$ & $1 \times 10^{6} / \mathrm{ml}$ & 62.0 & 93.1 & 93.3 \\
\hline \multirow{6}{*}{ (GTE-GSE) mixture } & $100 \mathrm{ng} / \mathrm{ml}$ & 28.7 & 92.5 & 92.2 \\
\hline & $300 \mathrm{ng} / \mathrm{ml}$ & 31.2 & 92.3 & 92.4 \\
\hline & $400 \mathrm{ng} / \mathrm{ml}$ & 46.2 & 93.5 & 93.7 \\
\hline & $500 \mathrm{ng} / \mathrm{ml}$ & 54.3 & 93.5 & 93.8 \\
\hline & $700 \mathrm{ng} / \mathrm{ml}$ & 59.8 & 93.2 & 93.4 \\
\hline & $1000 \mathrm{ng} / \mathrm{ml}$ & 69.3 & 92.8 & 92.7 \\
\hline \multirow{6}{*}{$\gamma$-irradiated samples } & $0.5 \mathrm{~Gy}$ & 11.4 & 92.7 & 92.4 \\
\hline & $1.5 \mathrm{~Gy}$ & 29.2 & 93.1 & 93.4 \\
\hline & $3.0 \mathrm{~Gy}$ & 41.8 & 93.2 & 93.5 \\
\hline & $6.0 \mathrm{~Gy}$ & 51.8 & 93.3 & 93.5 \\
\hline & 8.0 Gy & 62.3 & 93.2 & 93.6 \\
\hline & $10.0 \mathrm{~Gy}$ & 77.4 & 92.9 & 92.7 \\
\hline \multirow{3}{*}{$\begin{array}{l}\text { (GTE-GSE) mixture } \\
\text { combined with } \\
\gamma \text {-irradiation }\end{array}$} & $500 \mathrm{ng} / \mathrm{ml}+6.0 \mathrm{~Gy}$ & 62.7 & 93.2 & 93.5 \\
\hline & $700 \mathrm{ng} / \mathrm{ml}+6.0 \mathrm{~Gy}$ & 73.5 & 93.2 & 93.6 \\
\hline & $1000 \mathrm{ng} / \mathrm{ml}+6.0 \mathrm{~Gy}$ & 73.9 & 93.0 & 93.4 \\
\hline
\end{tabular}

GTE: green tea extract, GSE: grape seed extract, DPPH: Diphenylpicrylhydrazine, BHA: Butylated hydroxyanisole, BHT: Butylated hydroxytoluene.

\section{Discussion}

Polyphenols antioxidant in green tea extract and grape seed extract mixture (GTE-GSE mix) terminate the radical chain reactions that occur during the oxidation process and thus can act as free radical scavengers [51]. The active hydroxyl groups present in the molecular structure of polyphenols have demonstrated potential antioxidant properties due to their redox potential; this enables them to act in various forms such as hydrogen donors, reducing agents, nascent oxygen quenchers [52].

The strong antioxidant effect of phenolic antioxidant is due to an effective hydrogen donation, as well as effective delocalization of an unpaired electron. The 2, 3 double bond in the $\mathrm{C}$ ring in conjugation with the carbonyl in the $\mathrm{C} 4$ improves electron delocalization, which stabilizes the antioxidant radical [53]. 
Data illustrated in Fig. (1) are in a good agreement with Galati and O'Brien[54]. They reported that polyphenols are potent bioactive compounds that possess anti-carcinogenic activities. They interfere with the initiation, development and progression of cancer by modulating critical processes of cellular proliferation, differentiation, apoptosis, angiogenesis and metastasis. Chung and Hong [12] revealed that flavonoids have good effects on cancer chemoprevention and therapy. They may protect DNA from oxidative damage, inhibit carcinogen activation, activation of caspases and activate carcinogen detoxifying systems.

In this study, variable doses of $\gamma$-irradiation $(0.5$ to $10 \mathrm{~Gy}$ ) as illustrated in Fig (2) were used for treatment of myeloma cells, and the effective dose was determined ( 8 Gy). The results obtained indicated that the viability $(\%)$ of the cells decreased by increasing the dose of $\gamma$-irradiation used for treatment compared to that of the control group and this could be due to the direct effect of $\gamma$-irradiation on the DNA leading to a damage of the genetic materials of the cells and loss of clonogenic survival of myeloma cells [55].

From the obtained results in Fig. ( $3 b$ and $3 c$ ) it could be concluded that the dose of combined treatment $(700 \mathrm{ng} / \mathrm{ml}$ plus $6 \mathrm{~Gy})$ was more effective on the growth inhibition of myeloma cells than each treatment alone during six day. This may be due to the content of catechins and procyanidin polyphenols that rich in the active hydroxyl group, which can interact with the free radicals to exhibit scavenging activity against free radicals, superoxide radicals, peroxynitrite, chelate copper and iron, preventing metal catalyzed free radical formation [56].

Therefor polyphenols induce apoptosis in cancer cells without adversely affecting normal cells [57]. The antioxidant functions of the green tea polyphenol catechins depends on the structure, position and number of hydroxyl groups [58].

The caspases enzymes play essential roles in apoptosis, necrosis, and inflammation. Caspases function is achieved via the cleavage of some related proteins within the cells. Simply turned on caspases are responsible from turning off the process of cell survival [38]. The results suggested that these treatments induced activation of caspase-
8 and caspase-9 in myeloma cells leading to induction of extrinsic and intrinsic apoptotic pathways $[59,60]$.

It has been suggested that the production of reactive oxygen species (ROS) is a common mechanism in one of the representative pathways of apoptosis. Oxidant and its compounds are capable of depleting reduced glutathione (GSH) or damaging the cellular antioxidant defense system and can directly induce apoptosis $[61,62]$.

$\mathrm{DPPH}^{-}$is a stable radical showing a maximum absorbance at $517 \mathrm{~nm}$. In DPPH assay, the antioxidant (GTE- GSE mix) was able to reduce the stable radical DPPH to the yellow-colored diphenyl picrylhydrazone [63]. This method is based on the reduction of DPPH in alcoholic solution in the presence of a hydrogen-donating antioxidant due to formation of the non-radical form DPPH-H in the reaction. DPPH is usually used as a reagent to evaluate free radical and accepts an electron or hydrogen radical to become a stable molecule [64]. The disappearance of the DPPH radical absorption at $517 \mathrm{~nm}$ by the action of (GTE- GSE mix) antioxidant is taken as a measure of antioxidant activity. The obtained results in Table (2) indicated that a higher percentage of DPPH scavenging activity in case of GTE-GSE mix and $\gamma$-irradiation (700 $\mathrm{ng} / \mathrm{ml}$ plus 6 Gy) may be attributed to the higher total phenolic contents and flavonoids contents present in mixture.

\section{Conclusion}

The present study shows that the combined treatment with GTE-GSE mix plus $\gamma$-irradiation (700 $\mathrm{ng} / \mathrm{ml}$ plus $6 \mathrm{~Gy}$ ) had an antiproliferative effect which results in inhibiting the growth of cancer cells via the induction of apoptosis in vitro when compared with each agent alone. Also, GTEGSE mix plus $\gamma$-irradiation combination induced a synergistic apoptosis in myeloma cells.

\section{References}

1- Kyle, R.A. and Rajkumar, S.V. Multiple Myeloma, Blood, 111(6), 2962-2972 (2008).

2- Siegel, R.L., Miller, K.D. and Jemal, A. Cancer Statistics, CA: A, Cancer J. Clin., 66, 7-3 (2016).

3- Palumbo, A., Bringhen, S. and Caravita, T. Oral Melphalan and Prednisone Chemotherapy Plus 
Thalidomide Compared with Melphalan and Prednisone Alone in Elderly Patients with Multiple Myeloma: Randomized Controlled Trial, Lancet, 367, 825-31(2006).

4- Karori, S.M., Wachira, F.N., Wanyoko, J.K. and Ngure, R.M. Antioxidant Capacity of Different Types of Tea Products, Afr. J. Biotechnol., 6, $2287-$ 2296(2007).

5- Yilmaz, Y. Novel Uses of Catechins in Foods, Trends Food Sci. \& Technol., 17, 64-71(2006).

6- Naidu, A.S. Natural Food Antimicrobial Systems. In L. R. Juneja, T. Okubo, \& P. Hung (Eds.), Catechins (pp. 382). Florida: CRC press LLC(2000).

7- Dufresne, C. and Farnworth, E. Tea, Kombucha, and Health, A Review, Food Res. Int., 33, 409421(2000).

8- Frei, B. and Higdon, J.V. Antioxidant Activity of Tea Polyphenols in vivo, Evidence from Animal Studies, J. Nutr., 133, 3275S-3284S(2003).

9- Wiseman, S.A., Balentine, D.A. and Frei, B. Antioxidants in Tea, Crit. Rev. Food Sci. Nutr., 37, 705-708(1997).

10- Rietveld, A. and Wiseman, S. Antioxidant Effects of Tea: Evidence from Human Clinical Trials, J. Nutr. 133, 3285S-3292S(2003).

11- Cai, Y.J., Ma, L.P., Hou, L.F., Zhou, B., Yang, L. and Liu, Z.L. Antioxidant Effects of Green Tea Polyphenols on Free Radical Initiated Peroxidation of Rat Liver Microsomes, Chem. Phys. Lipids., 120, 109-117(2002).

12- Chung, S.Y. and Hong, W. Cancer Therapy Combination: Green Tea and a Phosphodiesterase 5 Inhibitor, J. Clin. Invest., 123 (2), 556-558(2013).

13- Lau, D.W. and King, A.J. Pre and Post-Mortem Use of Grape Seed Extract in Dark Poultry Meat to Inhibit Development of Thiobarbituric Acid Reactive Substances. J. Agric. Food Chem., 51, 1602-1607(2003).

14- Vigna, G.B., Constantini, F., Aldini, G., Carini, M., Catapano, A., Schena, F., Tangerini, A., Zanca, R., Bombardelli, E., Morazzoni, P., Mezzetti, A., Fellin, R., and Maffei-Facino, R. Effect of a Standardized Grape Seed Extract on Low-Density Lipoprotein Susceptibility to Oxidation in Heavy Smokers, Metabolism, 52, 1250-1257(2003).

15- Frankel, E.N., Waterhouse, A.L. and Teisssedre, P.L. Principle Phenolic Phytochemicals in Selected California Wines and Their Antioxidant Activity in Inhibiting Oxidation of Human Low-Density Lipoproteins, J. Agric. Food Chem., 43, 890894(1995).

16- Teissedre, P.L., Frankel E.N., Waterhouse, A.L., Pele, G.H. and German, J.B. Inhibition of in-vitro Human LDL Oxidation by Phenolic Antioxidants from Grapes and Wines, J. Sci. Food Agric., 70, 5561(1996).

17- Waterhouse, A.L. Wine Antioxidants May Reduce Heart Disease and Cancer, Presentation of American Chemical Society, Washington DC(1994).

18- Jayaprakasha, G.K., Singh, R.P. and Sakariah, K.K. Antioxidant Activity of Grape Seed (Vitis vinifera) Extracts on Peroxidation Models in vitro, Food Chem., 73, 285-290(2001).

19- Caillet, S., Salmieri, S. and Lacroix, M. Evaluation of Free Radical-Scavenging Properties of Commercial Grape Phenol Extracts by a Fast Colorimetric Method. Food Chem., 95:1-8(2006).

20- Gorinstein, S., Zemser, M., Weisz, M., Halevy, S., Deutsch, J., Tilis, K., Feintuch, D., Guerra, N., Fishman, M. and Bartnikowska, E. Fluorometric Analysis of Phenolics in Persimmons, Biosci. Biotech. Biochem., 58(6), 1087-1092(1994).

21- Uchida, S., Ozaki, M., Akashi, T., Yamashita, K., Niwa, M. and Taniyama, K. Effects of (-)Epigallocatechin-3-O-gallate (Green Tea Tannin) on the Life Span of Stroke-Prone Spontaneously Hypertensive Rats, Clin. Exp. Pharmacol. Physiol., 22, 302-303(1995).

22- Meeran, S.M. and Katiyar, S.K. Grape seed proanthocyanidins promote apoptosis in Human Epidermoid Carcinoma A431 Cells through Alterations in Cdki-Cdk-cyclin Cascade, and Caspase-3 Activation via Loss of Mitochondrial Membrane Potential, Exp. Dermatol., 16, 405 415(2007).

23- Sharma G., Tyagi A.K., Singh R.P., Chan D.C. and Agarwal R. Synergistic Anticancer Effects of Grape Seed Extract and Conventional Cytotoxic Agent Doxorubicin against Human Breast Carcinoma Cells, Breast Cancer Res. Treat., 85, 1-12(2004).

24- Engelbrecht, A.M., Mattheyse, M. and Ellis, B. Proanthocyanidin from Grape Seeds Inactivates the PI3- kinase/PKB Pathway and Induces Apoptosis in a Colon Cancer Cell Line, Cancer Lett., 258, 144153(2007).

25- Ye, X., Krohn, R.L., Liu, W., Joshi, S.S., Kuszynski, C.A., McGinn, T.R., Bagchi, M., Preuss, H.G., Stohs, S.J. and Bagchi, D. The Cytotoxic Effects of a Novel IH636 Grape Seed Proanthocyanidin Extract on Cultured Human Cancer Cells, Mol. Cell. Biochem., 196, 99108(1999).

26- Masood, A.S., Paola, N., Hemanta, K., Ramesh, B., Batchu, R.C., Bertheau, V., Munshi, R., Prabhala, M., Fulciniti, Y., Tzu T., Steven, P., Treon, R.K., Kenneth, C.A., and Nikhil, C. M. Specific Killing of Multiple Myeloma Cells by (-)-Epigallocatechin-3gallate Extracted from Green Tea: Biologic Activity 
and Therapeutic Implications, Blood j., 108, 2804 2810(2006)

27- Agarwal, C., Singh, R.P. and Agarwal, R. Grape Seed Extract Induces Apoptotic Death of Human Prostate Carcinoma DU145 Cells via Caspases Activation Accompanied by Dissipation of Mitochondrial Membrane Potential and Cytochrome c Release, Carcinogenesis, 23, 1869 - 1876(2002).

28- Bagchi, D., Bagchi, M., Stohs, S.J., Das, D.K., Ray, S.D., Kuszynski, C.A., Joshi, S.S. and Pruess, H.G. Free Radicals and Grape Seed Proanthocyanidin Extract: Importance in Human Health and Disease Prevention, Toxicol, 148, 187-197(2000).

29- Tyagi, A., Agarwal, R. and Agarwal, C. Grape Seed Extract Inhibits EGF-Induced and Constitutively Active Mitogenic Signaling but Activates JNK in Human Prostate Carcinoma DU145 Cells: Possible Role in Antiproliferation and Apoptosis, Oncogene, 22, 1302-1316(2003).

30- Kaur, M., Agarwal, R. and Agarwal, C. Grape Seed Extract Induces Anoikis and Caspase-Mediated Apoptosis in Human Prostate Carcinoma LNCaP Cells: Possible Role of a Taxia Telangiectasia Mutated-P53 Activation, Mol. Cancer Ther, 5, 1265 1274 (2005).

31-Spanos, G.A. and Wrolstad, R.E. Phenolics of Apple, Pear, and White Grape Juice and Their Changes with Processing and Storage-A Review, J. Agric. Food Chem., 40, 1478 - 1487(1992).

32- Bagchi, D., Garg, A. and Krohn, R.L. Oxygen Free Radical Scavenging Abilities of Vitamins C and E, and A Grape Seed Proanthocyanidins Extract in vitro, Res. Commun. Mol. Pathol. Pharmacol., 95, 179-189(1997).

33- Yilmaz, Y. and Toledo, R. Health Aspects of Functional Grape Seed Constituents, Trends Food Sci. Technol., 15, 422-433(2004).

34- El-Alfy, A., Ahmed, A. and Fatani, A. Protective Effect of Red Grape Seeds Proanthocyanidins Against Induction of Diabetes by Alloxan in Rats, Pharmacol. Res., 52, 264-270(2005).

35- Li, W.G., Zhang, X.Y., Wu, Y.J. and Tian, X. Antiinflammatory Effect and Mechanism of Proanthocyanidins from Grape Seeds, Acta Pharmacol. Sin., 22, 1117-20(2001).

36- Halpern, M.J., Dahlgren, A.L., Laakso, T., Dahlgren, J. and McAnulty, P.A. Red-wine Polyphenols and Inhibition of Platelet Aggregation: Possible Mechanisms, and Potential Use in Health Promotion and Disease Prevention, J. Int. Med. Res., 26, 171-180(1998).

37- Fuchs, Y. and Steller, H. Programmed Cell Death in Animal Development and Disease, Cell, 147, 742758(2011).
38- Parrish, A.B., Freel, C.D. and Kornbluth, S. Cellular Mechanisms Controlling Caspase Activation and Function, Cold Spring Harb. Perspect. Biol., 5(6), a008672. DOI: 10.1101/cshperspect.a008672 (2013)

39- David, R.M., Thorsten, B. and Tak, W.M. Caspase Functions in Cell Death and Disease, Cold Spring Harb. Perspect. Biol., Toronto, Ontario M5G 2C1, Canada, DOI: 10.1101/cshperspect.a008656(2013).

40- Shalini, S., Dorstyn, L., Dawar, S. and Kumar, S. Old, New and Emerging Functions of Caspases, Cell Death Differ., 22, 526-539(2015).

41- Miralbell, R., Molla, M., Arnalte, R., Cancles, S., Vargasa, E., Linero, D., WAteers, S., Nouet, P., Rouzaud, M. and Escude, L. Target Repositioning Optimization in Prostate Cancer: is IntensityModulated Radiotherapy under Stereotactic Conditions Feasible, Int. J. Radiat. Oncol. Biol. Phys., 59(2), 366-371(2004).

42- Gramza, A., Khokhar, S., Yoko, S., GliszczynskaSwiglo, A., Hes, M. and Korczak, J. Antioxidant Activity of Tea Extracts in Lipids and Correlation with Polyphenol Content, Eu. J. Lipid Sci. Technol., 108, 351-362(2006).

43- El-Beltagi, H., El-Desouky, W. and Yousef, R. Synergistic Antioxidant Scavenging Activities of Grape Seed and Green Tea Extracts against Oxidative Stress, Not. Bot. Horti. Agrobo., 44(2), 367-374. DOI: 10.15835/nbha44210358(2016).

44- Ahn, H., Jeona, T., Lee, J., Hwang, S., Lim, Y. and Park, D. Antioxidative Activity of Persimmon and Grape Seed Extract, in vitro and in vivo. Nutr. Res., 22, 1265-1273(2002).

45- El-Desouky, W., Hanafi, A. and Abbas, M. Radioprotective Effect of Green Tea and Grape Seed Extracts Mixture on Gamma Irradiation Induced Immune Suppression in Male Albino Rats. Int. J. Radiat. Biol., 93(4), 433-439(2017).

46- Chapmen, R.S. Nuclear Medicine and Related Radionuclide Application in Developing Countries, 2nd ed. p.17, Atomic energy agency, Vienna(1998).Masood, S., Robert J.,

47- Masood, S., Robert J., Shmookler, R., Cheng Li, H., Koley, L., Hurley, K.A. and Nikhil, M. (2004) Telomerase Inhibition and Cell Growth Arrest after Telomestatin Treatment in Multiple Myeloma, Clin. cancer res., DOI: 10.1158/1078-0432.CCR-0793-03.

48- Harlow, E. and David, L. Antibodies. A Laboratory Manual, 2nd Edition. P. 148-219. Cold spring Harbor laboratory press. New York, USA(1988).

49- Cristina, P., Guy, S.S. and Fiona, L.S. Caspase Assays: Identifying Caspase Activity and Substrates. In vitro and in vivo, Methods Enzymol., 351367(2008). 
50- Blois, M.S. Antioxidant Determinations by the Use of a Stable Free Radical, Nature, 26, 1199 . 1200(2002).

51- Turkoglu, A., Duru, M.E., Mercan, N., Kivrak, I. and Gezer, K. Antioxidant and Antimicrobial Activities of Laetiporus sulphureus (Bull.) Murill. Food Chem., 101, 267-273(2007).

52- Mitsumoto, M., O’Grady, M.N., Kerry, J.P. and Buckley, D.J. Addition of Tea Catechins and Vitamin C on Sensory Evaluation, Colour and Lipid Stability During Chilled Storage in Cooked or Raw Beef and Chicken Patties, Meat Sci., 69, 773779(2005).

53- Pekkarinen, S.S., Heinonen, I.M. and Hopia, A.I. Flavonoids Quercetin, Myricetin, Kaemferol and (+)-Catechin as Antioxidants in Methyl Linoleate, J. Sci. Food Agric., 79, 499-506(1999).

54- Galati, G., and O'Brien, P.J. Potential Toxicity of Flavonoids and Other Dietary Phenolics: Significance for their Chemopreventive and Anticancer Properties, Free Radic. Biol. Med., 37(3), 287-303(2004).

55- Lomax, M.E., Folkes, L.K., and Neill, P.O. Biological Consequences of Radiation-induced DNA Damage: Relevance to Radiotherapy, Clin. Oncol., 25, 578-585(2013).

56- Lin, J. and Liang, Y. Cancer Chemoprevention by Tea Polyphenols, Proceedings of the National Science Council, Republic of China B, 24(1), 113(2000).
57- Rice-Evans, C.A., Miller, N.G. and Paganaga, G. Antioxidant Properties of Phenolic Compounds, Trends Plant Sci., 2, 152-159(1997).

58- Hu, X.F., Yang, X.Q. and Liu, K.X. Structureactivity Relationship of Tea Polyphenols. Beijing, China, Beijing Science Press, 60-69(2001).

59- Riedl, S.J. and Shi, Y. Molecular Mechanisms of Caspase Regulation During Apoptosis, Nat. Rev. Mol. cell Biol., 5 (11), 897-907(2004).

60- Galluzzi, L., Lopez-Soto, A., Kumar, S. and Kroemer, G. Caspases Connect Cell-Death Signaling to Organismal Homeostasis, Immunity, 44 (2), 221-231(2016).

61- Mcllwain, D.R., Berger, T. and Mak, T.W. Caspase Functions in Cell Death and Disease, Cold Spring Harb. Perspect. Biol., 5(4), a008656. DOI: 10.1101/cshperspect.a008656(2013).

62- Brentnall, M., Rodriguez-Menocal, L., De Guevara, R.L., Cepero, E. and Boise, L.H. Caspase-9, Caspase-3 and Caspase-7 Have Distinct Roles During Intrinsic Apoptosis, BMC Cell Biol, 14, 32(2013).

63- Frankel, E. and Meyer, A. The Problems of using One-dimensional Methods to Evaluate Multifunctional Food and Biological Antioxidants, J. Sci. Food Agri., 80, 1925-1941(2000).

64- Oyaizu, M. Studies on Products of Browning Reaction: Antioxidative Activity of Products of Browning Reaction Prepared from Glucosamine, Jap. J. Nutr., 44, 307- 315(1986). 